\title{
Analisis Kinerja Jaringan Internet Menggunakan Metode Class Based Queueing (CBQ) di Universitas Dhyana Pura
}

\author{
I Nyoman Bernadus $^{1}$, Nyoman Gunantara ${ }^{2}$, Komang Oka Saputra ${ }^{3}$ \\ [Submission: 19-02-2019, Accepted: 22-04-2019]
}

\begin{abstract}
All universities certainly have the desire to build a good internet service system for the satisfaction realization of the entire academic community. However, in reality, not all universities have achieved the ideal condition, one of those universities is the University of Dhyana Pura. Based on the observation results, the problems is that the bandwidth managements are not well managed. This study aims to analyze the Quality of Service (QoS) with parameters throughput, delay, packet loss, jitter and bandwidth. The results of this study show that CBQ method is a better bandwidth management method in limiting bandwidth for client with bandwidth crisis, with an average throughput value of 59.55 bps (Good), $89.2 \mathrm{~ms}$ delay (Very Good), packet loss 4.2\% ( Good), jitter for 6 ms (Good). Measuring the level of satisfaction using the Customer Satisfaction Index (CSI) method with a total satisfaction index reaching 62, 24\% in the category of Satisfied Enough.

Intisari-Semua Universitas tentu memiliki keinginan untuk membangun sistem layanan internet yang baik demi terwujudnya kepuasan seluruh civitas akademika. Namun, kenyataannya belum semua universitas mencapai kondisi tersebut, salah satunya adalah Universitas Dhyana Pura. Berdasarkan hasil observasi masalah yang dihadapi pengelolaan bandwidth tidak terkelola dengan baik. Penelitian ini bertujuan untuk menganalisa Quality of Service (QoS) dengan parameter-parameter throughput, delay, packet loss, jitter dan bandwidth. Hasil penelitian ini menampilkan metode CBQ merupakan metode manajeman bandwidth yang baik dalam melimitasi bandwidth pada client yang krisis bandwidth, dengan nilai rata-rata troughput 59,55 bps (Bagus), delay 89,2 ms (Sangat Bagus), packet loss 4,2\% (Bagus), jitter sebesar $6 \mathrm{~ms}$ (Bagus). Pengukuran tingkat kepuasan menggunakan metode Customer Satisfaction Index (CSI) dengan total indeks kepuasan mencapai 62, 24\% dalam kategori Cukup Puas.
\end{abstract}

Kata Kunci-Class Based Queuing (CBQ), Customer Satisfaction Index (CSI), Manajemen Bandwidth, Parameter QoS.

\section{PENDAHULUAN}

Perkembangan Teknologi Informasi dan Komunikasi (TIK) dari waktu ke waktu terus meningkat mengakibatkan

kebutuhan akan informasi secara cepat dan tepat menjadi sebuah tuntutan baik dalam pemerintahan, pendidikan, dan bisnis. Salah satu media elektronik yang paling efisien dalam

${ }^{1}$ Mahasiswa, Magister Teknik Elektro Universitas Udayana, Jl. P.B. Sudirman, Denpasar, Bali, Indonesia 80114 (tlp: 0361555225; fax:0361-4321982; e-mail: balitorock@gmail.com)

2, 3 Dosen, Magister Teknik Elektro Universitas Udayana, Jl. P.B. Sudirman, Denpasar, Bali, Indonesia 80114 (tlp: 0361555225; fax: 0361-4321982; e-mail: gunantara@unud..ac.id), okasaputra@unud.ac.id

I Nyoman Bernadus: Analisis Kinerja Jaringan Internet ... menyebar dan menerima informasi adalah internet [1]

Kebutuhan dunia pendidikan akan akses internet sangat tinggi seperti Universitas Dhyana Pura (Undhira), Seiring dengan kemajuan Universitas dan pengembangan kampus diantaranya dalam bidang teknologi, sistem manual perlahanlahan beralih menggunakan teknologi informasi. Teknologi informasi yang berkembang pada saat ini ialah sistem informasi akademik, sistem informasi keuangan, dan kepegawaian, agar semua sistem berjalan dengan baik maka ketersediaan layanan jaringan internet harus diutamakan, dimana jumlah bandwidth sebesar $20 \mathrm{Mbps}$ dan di alokasikan ke jaringan Local Area Network (LAN) ke masing-masing ruangan tiap-tiap pegawai, dengan jumlah pengguna internet sebanyak 80 pegawai. Keterbatasan dan tidak adanya pengelolaan manajeman bandwidth akan menghambat laju perkembangan proses pembelajaran pada mahasiswa, tenaga pendidik, peningkatan mutu pendidikan, dan pelayanan administrasi pendidikan.

Berdasarkan data observasi masalah yang dihadapi adalah keluhan pengguna internet di kampus dalam proses pengiriman maupun penerimaan data yang sering mengalami gangguan (lambat), atau biasa disebut bandwidth overload, terlebih disaat banyaknya pemakaian internet pada jam kerja, yang disebabkan oleh tidak adanya pengelolaan manajeman bandwidth yang baik. Hal ini dapat mengakibatkan terjadinya beberapa masalah seperti menurunnya kecepatan konektifitas jaringan, delay, kehilangan data dalam pengiriman / packet loss dan mengakibatkan nilai jitter akan semakin meningkat, ketidakmampuan mengalokasikan jumlah bandwidth secara tepat dapat mengakibatkan mekanisme pemrosesan data menjadi terhambat, mempengaruhi kinerja organisasi menyeluruh [2], sehingga menjadikan layanan komunikasi tidak efektif dari kegagalan proses transmisi data, unggah dan unduh mengalami delay, yang mengakibatkan tumpukan antar paket data (congestion), hardware latency, loses [3].

Bandwidth management merupakan cara dalam menerapkan dan mengoptimalkan berbagai tipe jaringan, bandwidth management digunakan untuk menentukan tipetipe lalu lintas melalui layanan Quality of Service (QoS) [4]. Dalam komunikasi data QoS mampu menampilkan suatu tingkat pencapaian dalam suatu sistem [5]. Tujuan ialah memenuhi suatu kebutuhan layanan yang berbeda-beda pada infrastruktur yang sama, QoS mampu menjelaskan atributatribut layanan secara kualitatif ataupun kuantitatif, dan memegang peranan sangat penting dalam manajemen bandwidth [6]. QoS digunakan untuk mengukur tingkat kinerja koneksi seperti throughput, delay, packet loss, jitter dan bandwidth jaringan TCP/IP internet atau jaringan komputer [7].

p-ISSN:1693 - 2951; e-ISSN: 2503-2372 
Analisis terhadap Quality of Service (QoS) dengan metode CBQ (Class Based Queueing) pada penelitian [8], [9], [10], [11] dimana metode CBQ (Class Based Queueing) merupakan metode disiplin antrian pada jaringan internet yang diterapkan dalam manajemen bandwidth dengan beberapa parameter. Dengan digunakannya metode CBQ dalam analisis Quality of Service (QoS) penelitian ini berfokus bagaimana CBQ sebagai suatu metode antrian dalam menerapkan QoS dari hasil pembagian bandwidth, dengan pengukuran interval waktu sibuk dan tidak sibuk. Implementasi metode CBQ di Linux Ubuntu 16.04 menggunakan webmin dalam melakukan pembagian bandwidth, dengan harapan mampu memberikan kualitas layanan yang merata dan adil sehingga dapat mendukung dan meningkatkan pelayanan terhadap mahasiswa serta kepuasan layanan terhadap pegawai di Universitas Dhyana Pura.

\section{TINJAUAN PUSTAKA}

\section{A. Quality of Service (QoS)}

Quality of Service (QoS) mendefinisikan kehandalan sebuah jaringan dalam menyediakan layanan yang baik bagi layanan trafik yang melewatinya. Terdapat jenis (parameter) dari QoS, yaitu (1) Throughput diukur dalam satuan bps (bit per second) ialah kecepatan (rate) transmisi data efektif. (2) Delay waktu tempuh yang dibutuhkan oleh data (informasi) dari titik awal ke titik tujuan, dipengaruhi dari jarak, hardware, ataupun kongesti, (3) packet loss didefinisikan sejumlah paket yang tidak sampai (gagal) pada waktu paket dikirim. packet loss besar di definisikan jaringan sedang sibuk (overload). (4) Variasi delay antar paket yang terjadi pada jaringan disebut jitter. Nilai jitter yang tinggi disebabkan adanya variasi beban trafik dan tumbukan antar paket yang besar (congestion), sementara (5) bandwidth (lebar pita) merupakan kecepatan transfer data (transfer rate) maksimal yang di dapat dan diteruskan antara dua titik dalam kurun waktu tertentu, dihitung dalam satuan bit per second (bps) [12].

\section{B. Class Based Queueing (CBQ)}

Dalam manajemen bandwidth dikenal istilah queuing merupakan penjadwalan suatu data dikirimkan melewati jaringan. CBQ ialah teknik disiplin antrian yang digunakan untuk mengelompokkan paket data dan mengizinkan sharing bandwidth antar kelas yang mempunyai user interface. CBQ mengelola pemakaian bandwidth jaringan yang diberikan untuk tiap user, pemakaian bandwidth yang melebihi nilai set akan dipotong (shaping), keunggulan link sharing dapat memberikan bandwidth yang tak terpakai bagi leaf classnya sebelum diberikan kepada agensi-agensi lain. Kelemahan dari CBQ adalah alokasi bandwidth dibagi secara adil jika paket semua antrian memiliki sama (atau sebanding) ukuran. Diagram blok kerja dapat dilihat pada Gambar 1.

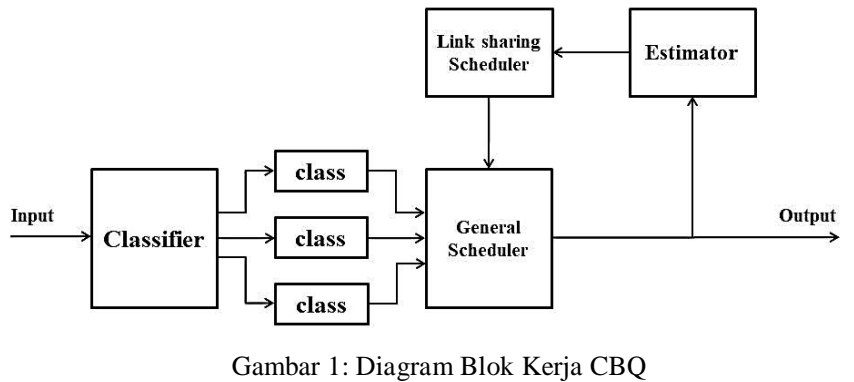

Gambar 1 menjelaskan ketika suatu paket datang, maka classifier memilih paket dan menempatkannya ke class yang bersesuaian, kemudian class tersebut akan mendapatkan bandwidth yang dibagikan oleh general scheduler kepada setiap class sesuai dengan alokasi masing-masing. Sebelum paket dikeluarkan, bagian estimator akan memeriksa apakah setiap class memperoleh bandwidth yang dialokasikan, bila suatu class kekurangan, maka link sharing scheduler akan meminjamkan bandwidth dari kelas yang memiliki bandwidth tidak terpakai ke kelas yang memerlukan tambahan bandwidth.

\section{Kepuasan Pelanggan}

Kepuasan merupakan tingkat keadaan yang dirasakan (senang atau kecewa) seseorang dari membandingkan hasil dan harapan suatu produk. [13]. Label yang digunakan dalam meringkas himpunan tindakan (aksi) yang diamati terhadap produk atau jasa merupakan istilah dari kepuasan pelanggan [14]. Dari pernyataan para ahli didefinisikan bahwa kepuasan pelanggan adalah respon yang ditunjukan setelah membandingan dari persepsi (kinerja) yang dirasakan dengan kepentingan (harapan) oleh pelanggan. Apabila persepsi (kinerja) dirasakan melebihi dari kepentingan (harapan) maka pelanggan merasa sangat puas, bila sesuai akan merasa puas, namun sebaliknya apabila persepsi (kinerja) dirasa kurang dari kepentingan (harapan) pelanggan merasa kurang puas bahkan tidak puas [15].

Indeks kepuasan pelanggan merupakan tingkat kepuasan pelanggan didapat antara hasil pengukuran kuantitatif serta kualitatif, dari data dan informasi dengan membandingkan kepentingan (harapan) dan persepsi (kinerja)[16].

\section{METODE PENELITIAN}

Penelitian adalah suatu cara untuk mendapatkan suatu tujuan tertentu. Gambar 2 merupakan tahapan penelitian Penyusunan Penelitian Jaringan Internet dengan menggunakan metode CBQ di Universitas Dhyana Pura: 


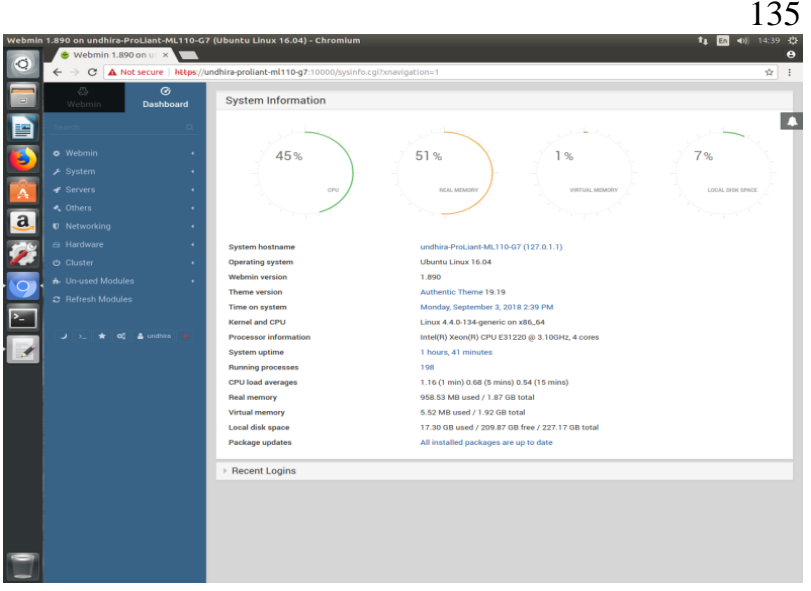

Gambar 3: Tampilan menu webmin

3) Monitoring kinerja jaringan bertujuan untuk mengambil infomasi lalu lintas paket data, menganalisa trafik jaringan dengan sampel www.ecampuz.undhirabali.ac.id dan www. gmail.com. Pengukuran dilakukan dengan pembagian waktu sibuk yaitu pada waktu 08:00 s/d 12:00 WITA selanjutnya 13:00 s/d 16:00 WITA, dan tidak sibuk pada waktu 16:00 s/d 20:00 WITA. Pengukuran ini dilakukan pada metode CBQ dari tanggal 10 September sampai 12 September 2018. Pengukuran kinerja jaringan internet yang digunakan untuk memantau arus lalu lintas paket data dengan menggunakan software Axence NetTools [17] antaranya throughput, delay, packet loss, sedangkan untuk jitter dan bandwidth menggunakan Biznet Speed Test [18].

4) Merancang kuesioner sebagai alat penelitian dengan cara penyebaran instrumen kepada para responden dengan total 80 pegawai yang terkoneksi pada jaringan LAN, menggunakan teknik total sampling, Adapun penilaian jawaban responden dari kriteria pengukuran ini dengan menggunakan Skala Likert dengan 5 alternatif persepsi kepuasan pada Tabel 1 .

TABEL I

SKala PENGUKURAN CUSTOMER SATISFACTION INDEX (CSI)

\begin{tabular}{|c|c|}
\hline Nilai & Keterangan \\
\hline 1 & Sangat tidak puas (STP) \\
\hline 2 & Tidak Puas (TP) \\
\hline 3 & Cukup (C) \\
\hline 4 & Puas (P) \\
\hline 5 & Sangat Puas (SP) \\
\hline
\end{tabular}

Pengukuran yang dilakukan pada parameter throughput adalah (1) Kecepatan jaringan internet dalam melakukan browsing, (2) Waktu untuk membuka halaman situs www.ecampuz.undhirabali.ac.id, (3) Kemampuan jaringan internet dalam melakukan download dan upload file dalam jumlah banyak pada www.ecampuz.undhirabali.ac.id, (4) Waktu untuk membuka situs www.gmail.com, (5) Kemampuan jaringan internet dalam melakukan download dan upload file dalam jumlah banyak dengan menggunakan akun gmail, (6) Kecepatan jaringan internet saat ini mencukupi dalam mencari informasi pada web google.

Pengukuran yang dilakukan pada parameter delay adalah: (1) Waktu yang dibutuhkan untuk terhubung dalam melakukan login ke akun www.ecampuz.undhirabali.ac.id, (2)

p-ISSN:1693 - 2951; e-ISSN: 2503-2372

I Nyoman Bernadus: Analisis Kinerja Jaringan Internet ... 
Tidak pernah mengalami penundaan yang lama dalam pengiriman data di www.ecampuz.undhirabali.ac.id, (3) Kecepatan jaringan internet dalam mencari informasi pada web www.ecampuz.undhirabali.ac.id, (4) Tidak pernah mengalami kegagalan dalam download maupun upload data menggunakan akun gmail.

Pengukuran yang dilakukan pada parameter packet loss adalah (1) Tidak pernah mengalami kegagalan dalam membuka situs www.ecampuz.undhirabali.ac.id, (2) Data yang dikirim menggunakan akun www.ecampuz.undhirabali.ac.id tidak pernah mengalami kerusakan ataupun kehilangan data, (3) Tidak pernah mengalami kegagalan dalam membuka situs www.gmail.com, (4) Data yang dikirim menggunakan akun gmail tidak pernah mengalami kerusakan ataupun kehilangan data.

Pengukuran yang dilakukan pada parameter jitter adalah (1) Jaringan internet sangat stabil pada saat melakukan transfer file melalui akun gmail, (2) Jaringan internet sangat stabil saat melakukan proses administrasi pada www.ecampuz.undhirabali.ac.id, (3) delay yang terjadi pada saat membuka beberapa akun gmail, (4) delay yang terjadi pada saat membuka beberapa akun pada www.ecampuz.undhirabali.ac.id.

Pengukuran yang dilakukan pada parameter bandwidth adalah (1) kecepatan akses internet saat mencari informasi pada website, (2) Kecepatan akses internet saat mentransfer file (download/upload), (3) bandwidth yang disediakan mencukupi dalam mengolah file pada akun gmail, (4) bandwidth yang disediakan mencukupi mengolah file pada www.ecampuz.undhirabali.ac.id

5) Melakukan validitas isi (content validity) dan reliability dengan menggunakan Microsoft Excel.

6) Melakukan analisis terhadap hasil analisa dari tahapan keempat dan tahapan kelima, dengan melakukan pengukuran indeks kepuasan pada Tabel II.

\section{TABEL II}

KRITERIA CUSTOMER SATISFACTION INDEKS (CSI)

\begin{tabular}{|c|c|}
\hline Nilai Indeks (\%) & $\begin{array}{c}\text { Kriteria Customer Satisfaction } \\
\text { Indeks }\end{array}$ \\
\hline $81,00-100,00$ & Sangat Puas \\
\hline $66,00-80,99$ & Puas \\
\hline $51,00-65,99$ & Cukup Puas \\
\hline $35,00-50,99$ & Kurang Puas \\
\hline $0,00-34,99$ & Tidak Puas \\
\hline
\end{tabular}

Sumber : Irawan (2004)

\section{HASIL DAN PEMBAHASAN}

Kampus Universitas Dhyana Pura memiliki 4 (empat) gedung yang diberi nama gedung $\mathrm{A}, \mathrm{B}, \mathrm{C}$, dan gedung $\mathrm{D}$, dimana konfigurasi akses pengguna internet dipusatkan pada 1 tempat, yaitu Information and Communication Technologies (ICT) yang terletak digedung B. Topologi jaringan yang digunakan adalah topologi Extended Star, ditunjukan pada Gambar 4.

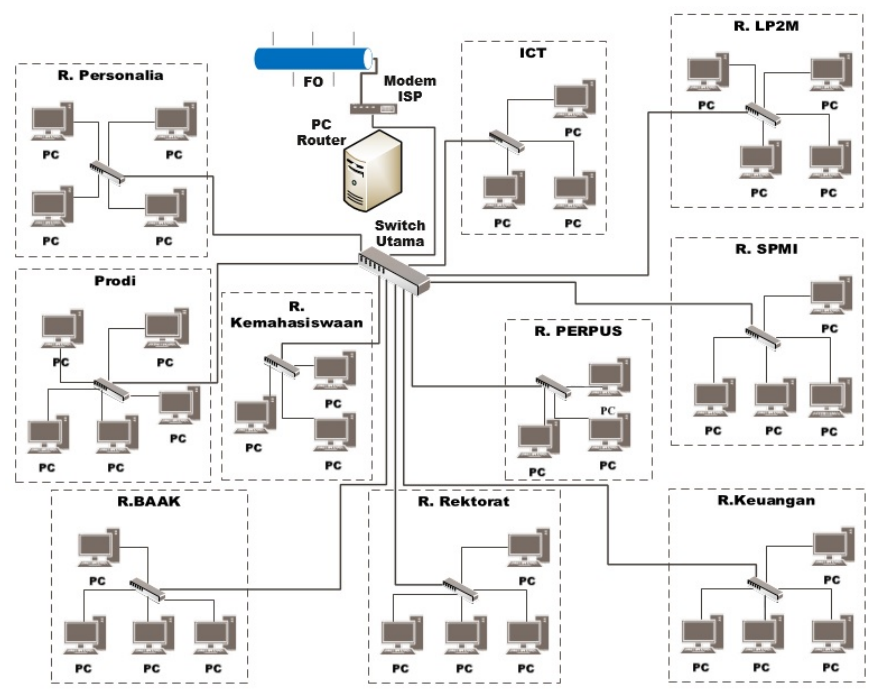

Gambar 4: Topologi Jaringan di Universitas Dhyana Pura

Pada Gambar 4 dapat dijelaskan jaringan lokal kampus bahwa PC router terhubung langsung ke modem ISP, dari router utama menuju ke switch utama, dan terhubung dengan switch yang terdapat di masing - masing ruangan gedung $\mathrm{B}$. Kabel ethernet jenis UTP (Unshield Twisted Pair) Cat 6 yang menghubungkan PC router dan switch utama pada server dan switch dimasing-masing ruangan. Sedangkan kabel ethernet jenis UTP (Unshield Twisted Pair) Cat 5 digunakan untuk menghubungkan ke masing-masing client yang berjumlah 80 PC. Dari daftar switch pada masing - masing ruangan maka dapat dilakukan pembagian bandwidth, seperti pada Tabel III.

TABEL III

DAFTAR PC YANG TERKONEKSI JARINGAN INTERNET

\begin{tabular}{|c|l|c|c|}
\hline No & Lokasi Switch & $\begin{array}{c}\text { Jumlah } \\
\text { PC }\end{array}$ & $\begin{array}{c}\text { Bandwidth } \\
\text { (Kbps) }\end{array}$ \\
\hline 1 & ICT & 4 & 256 \\
\hline 2 & Keuangan & 4 & 256 \\
\hline 3 & BAAK & 5 & 256 \\
\hline 4 & Rektorat & 3 & 256 \\
\hline 5 & Kepegawaian & 4 & 256 \\
\hline 6 & Perpustakaan & 3 & 256 \\
\hline 7 & Prodi & 46 & 256 \\
\hline 8 & SPMI & 3 & 256 \\
\hline 9 & LP2M & 5 & 256 \\
\hline 10 & Kemahasiswaan & 3 & 256 \\
\hline \multicolumn{2}{|r}{ Jumlah } & 80 & $20 \mathrm{Mbps}$ \\
\hline
\end{tabular}

Konfigurasi pembagian bandwidth pada metode CBQ dilakukan pada client seperti pada Gambar 5 dengan konfigurasi yaitu:

DEVICE=eth1,10Mbit,1Mbit

RATE $=256 \mathrm{Kbit}$

WEIGHT $=25.6 \mathrm{Kbit}$

$\mathrm{PRIO}=1$

$\mathrm{LEAF}=\mathrm{sfq}$

RULE $=192.168 .10 .0 / 24$

Artinya pemberian bandwidth sebesar $256 \mathrm{Kbps}$ kesemua client yang akan terhubung keinternet dengan gateway 192.168.10.0/24. 


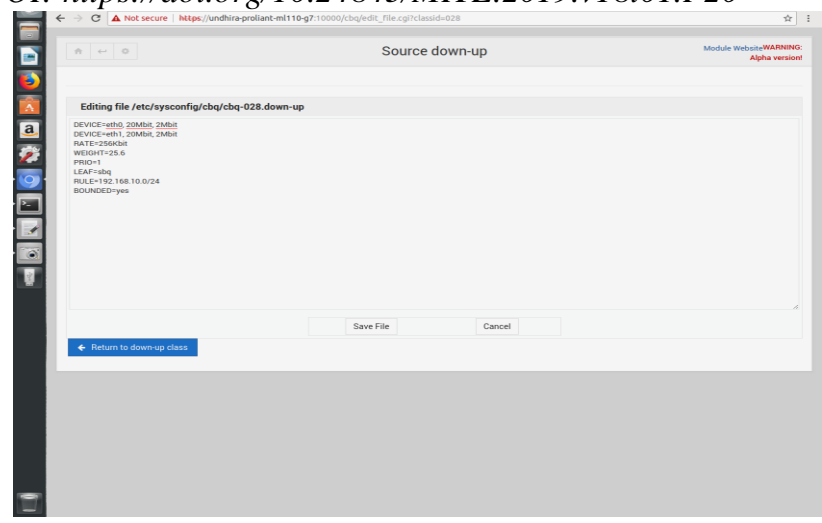

Gambar 5: Tampilan menu webmin pembagian bandwidth

A. Hasil Pengukuran Throughput pada Kondisi Eksisting dan Metode $C B Q$

Hasil pengukuran throughput pada kondisi eksisting dan metode CBQ dapat dilihat pada gambar 6.

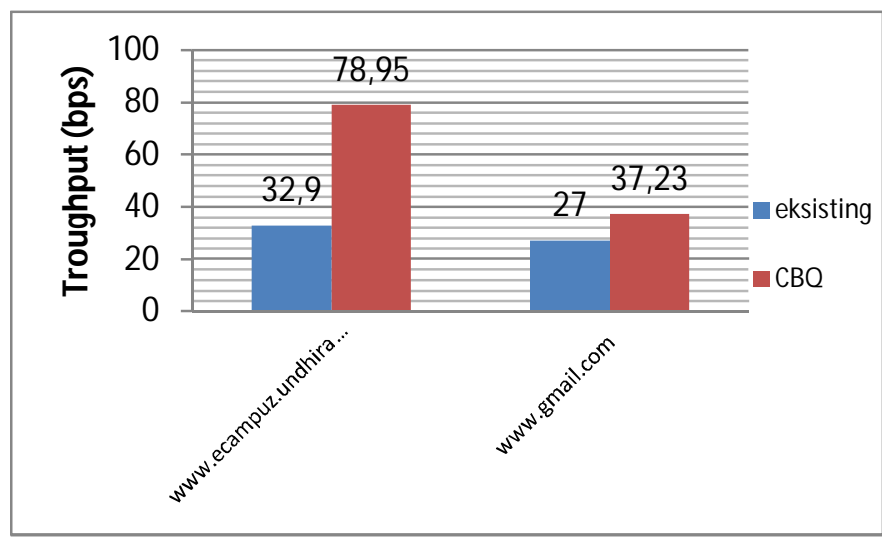

Gambar 6: Grafik Hasil Pengukuran Troughput pada kondisi Eksisting dan Metode CBQ.

Menurut standar versi TIPHON [7], troughput dikatakan sangat bagus jika bernilai 100 bps, bagus jika bernilai 75 bps, sedang jika bernilai 50 bps dan jelek jika bernilai kurang dari 25 bps. Dari grafik pada Gambar 6 throughput pada www.ecampuz.undhirabali.ac.id mengalami peningkatan sebesar 46,05 bps. sedangkan www.gmail.com sebesar 10,23 bps. Maka dengan menggunakan metode CBQ berhasil meningkatkan rata-rata throughput dari 29,95 bps menjadi 58,09 bps. Dengan demikian throughput masuk dalam kategori Bagus.

\section{B. Hasil Pengukuran Delay pada Kondisi Eksisting dan Metode $C B Q$}

Hasil pengukuran delay pada kondisi eksisting dan metode CBQ dapat dilihat pada Gambar 7.

I Nyoman Bernadus: Analisis Kinerja Jaringan Internet ...

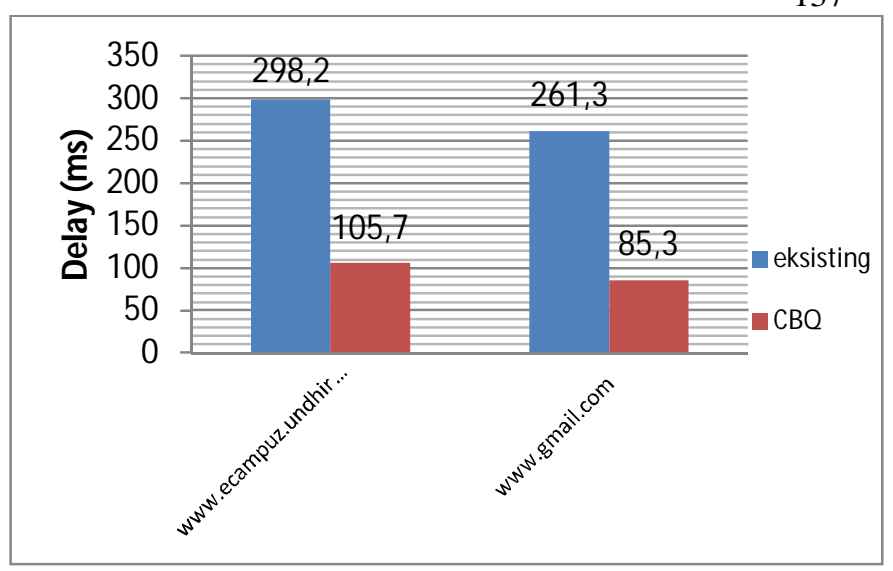

Gambar 7: Grafik Hasil Pengukuran Delay pada pada kondisi Eksisting dan Metode CBQ

Gambar 7 menunjukkan pengukuran delay dengan metode CBQ mampu menurunkan delay dari kondisi eksisting. Menurut standar versi TIPHON [7], delay kurang dari $150 \mathrm{~ms}$ dinyatakan sangat baik, bagus dengan nilai 150 sampai 300 ms, sedang 300 sampai $450 \mathrm{~ms}$, dan jelek nilainya lebih dari 450 ms. Dari grafik pada Gambar 8 maka hasil pengukuran delay pada www.ecampuz.undhirabali.ac.id mengalami penurunan sebesar 192,5 ms. sedangkan pada www.gmail.com sebesar $176 \mathrm{~ms}$. Metode CBQ berhasil menurunkan rata-rata delay dari 279,75 ms menjadi 95,5 ms. Dengan demikian delay masuk dalam kategori Sangat Bagus.

\section{Hasil Pengukuran Packet loss pada Kondisi Eksisting dan Metode $C B Q$}

Hasil pengukuran Packet loss dapat dilihat pada Gambar 8 .

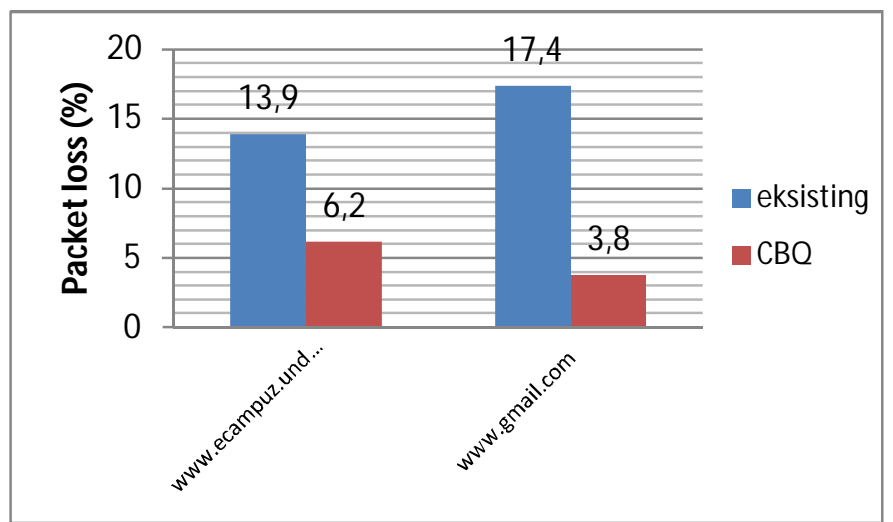

Gambar 8: Grafik Hasil Pengukuran Packet loss pada kondisi Eksisting dan Metode CBQ

Gambar 8 menunjukkan hasil dari pengukuran packet loss pada kondisi eksisting dan metode CBQ. Menurut standar versi TIPHON [7] Packet loss dikategorikan sangat bagus jika bernilai $0 \%$, bagus apabila bernilai $3 \%$, jika bernilai $15 \%$ disebut sedang, dan jika bernilai di atas $25 \%$ adalah jelek. Gambar 8 packet loss pada www.ecampuz.undhiabali.ac.id mengalami penurunan sebesar 7,7\%. Sedangkan pada www.gmail.com sebesar 13,6\%. Dengan demikian metode CBQ berhasil menurunkan rata-rata packet loss dari $15,65 \%$ menjadi 5\%, yaitu dengan kategori Bagus.

p-ISSN:1693 - 2951; e-ISSN: 2503-2372 


\section{Hasil Pengukuran Jitter pada Kondisi Eksisting dan Metode $C B Q$}

Menurut standar versi TIPHON [7], jitter dikatakan sangat bagus jika bernilai 0 , bagus nilai 0 sampai dengan $75 \mathrm{~ms}$, nilai 75 sampai dengan $125 \mathrm{~ms}$ sedang, dan 125 - $225 \mathrm{~ms}$ dikategorikan jelek. Grafik pada Gambar 9 menunjukkan bahwa hasil pengujian jitter pada metode CBQ dengan ratarata jitter dari $181,7 \mathrm{~ms}$ menjadi $7,3 \mathrm{~ms}$ dengan kategori Bagus.

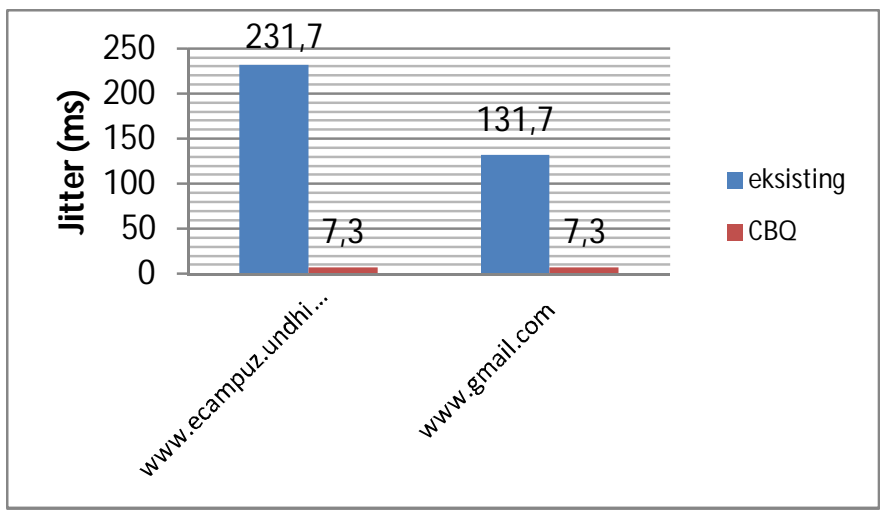

Gambar 9: Grafik Hasil Pengukuran Jitter pada kondisi Eksisting dan Metode CBQ

\section{E. Perbandingan Pengukuran Kondisi Eksisting dan dengan} Menggunakan Metode $C B Q$

Dari Gambar nilai rata-rata tiap parameter di atas maka, dapat disimpulkan kualitas kinerja jaringan internet pada tiap tiap parameter QoS dalam kondisi jaringan sibuk dan tidak sibuk di Universitas Dhyana Pura pada Tabel IV.

TABEL IV

PERBANDINGAN Kondisi EKSISTING DAN METODE CBQ

\begin{tabular}{|c|c|c|c|c|c|}
\hline \multirow{2}{*}{ Metode } & \multirow[b]{2}{*}{$\begin{array}{l}\text { Kondisi } \\
\text { Jaringan }\end{array}$} & \multicolumn{4}{|c|}{ Parameter Quality Of Service (QoS) } \\
\hline & & Troughput & Delay & $\begin{array}{c}\text { Packet } \\
\text { loss }\end{array}$ & Jitter \\
\hline \multirow{3}{*}{ Eksisting } & Jam Sibuk & 21,5 & 401,1 & 22,5 & 330,1 \\
\hline & Jam tidak sibuk & 64,6 & 37 & 3,5 & 34,6 \\
\hline & Rata-rata & 43,1 & 219 & 13.04 & 182,4 \\
\hline \multirow{4}{*}{ CBQ } & TIPHON & Sedang & Sedang & Sedang & Jelek \\
\hline & Jam Sibuk & 59,7 & 106,3 & 6,4 & 7,3 \\
\hline & Jam tidak sibuk & 59,5 & 73,2 & 2 & 4,6 \\
\hline & Rata-rata & 59,6 & 89,2 & 4,2 & 6 \\
\hline \multicolumn{2}{|c|}{ TIPHON } & Bagus & $\begin{array}{l}\text { Sangat } \\
\text { Bagus }\end{array}$ & Bagus & Bagus \\
\hline
\end{tabular}

\section{F. Hasil Pengukuran Kuesioner}

Berdasarkan hasil penyebaran kuesioner yang dilakukan pada tanggal 13 September 2018 untuk mendapatkan data mengenai kepuasan pengguna layanan jaringan internet dengan CBQ di Universitas Dhyana Pura, dengan 5 variabel yang diukur untuk mendapatkan nilai rata-rata kepuasan pengguna dari kualitas layanan berdasarkan parameter throughput, delay, packet loss, jitter dan bandwidth. Hasil dari pengukuran Customer Satisfaction Index (CSI) pada responden terhadap kepuasan pegawai dengan menggunakan metode CBQ pada jaringan internet Universitas Dhyana Pura yang meliputi variabel throughput, delay, packet loss, jitter, dan bandwitdth. Dapat dilihat pada Gambar 10.

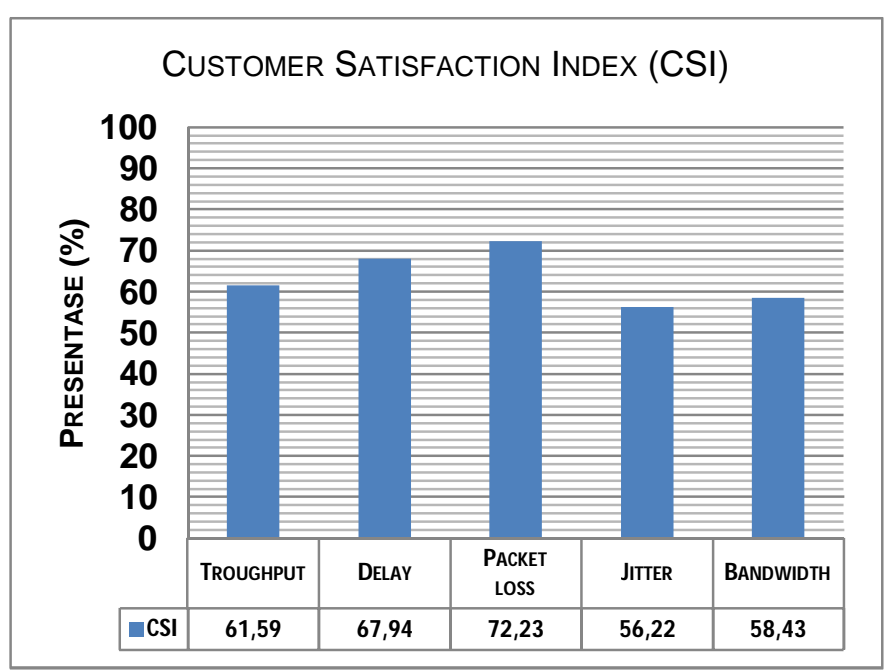

Gambar 10: Grafik Customer Satisfaction Index (CSI) parameter QoS pada Metode CBQ

Gambar 10 menyatakan hasil dari pengukuran Customer Satisfaction Index (CSI) dari pengguna jaringan internet LAN di Universitas Dhyana Pura menyatakan bahwa kinerja jaringan internet dengan menggunakan metode CBQ dengan total indeks kepuasan $62.24 \%$ kategori cukup puas, dengan nilai variabel troughput sebesar $61.59 \%$, delay sebesar $67.94 \%$, packet loss $72.23 \%$, jitter sebesar $56.22 \%$ dan bandwidth sebesar $58,43 \%$.

\section{KESIMPULAN}

Berdasarkan hasil implementasi dan pengukuran kinerja jaringan internet secara keseluruhan bahwa metode ini dapat menjadi solusi dalam manajemen bandwidth ketika terjadi overload bandwidth pada jam sibuk. Metode CBQ membagi bandwidth dengan sama rata dan bersifat tetap dengan nilai rata-rata QoS untuk parameter troughput sebesar 59,55 bps (Bagus), delay sebesar 89,2 ms (Sangat Bagus), packet loss 4,2\% (Bagus), jitter sebesar $6 \mathrm{~ms}$ (Bagus). sedangkan Indeks Kepuasan pada metode CBQ Total nilai $62,24 \%$ dalam kategori Cukup Puas, dengan nilai variabel troughput sebesar $61.59 \%$, delay sebesar $67.94 \%$, packet loss $72.23 \%$, jitter sebesar $56.22 \%$ dan bandwidth sebesar 58,43\%. Pengembangan berikutnya sebaiknya dicoba dengan metode seperti FIFO (First In First Out), HTB (Hierarchy Token Bucket), dan SFQ (Stochastic Fairness Queuing) yang merupakan teknik disiplin antrian dalam menganalisa kinerja jaringan internet dalam meningkatkan QoS.

\section{REFERENSI}

[1] Internet and A. P. Jasa, "Penetrasi \& Perilaku Pengguna Internet Indonesia," Apjii, vol. 2018, no. 31 August 2018, p. Hasil Survey, 2017.

[2] S. Kosasi, "Analisis Penerapan Arsitektur Wireless LAN Menggunakan Top Down Approach Pada PT . TELKOM Pontianak," Tek. Komput. Jar., vol. 1, no. 2, pp. 26-42, 2011. 
[3] Behrouz A. Forouzan, "Data Communication and Networking." p. 1,164, 2007.

[4] Sukri and P. S. Ira, "Analisis Penerapan Metode Antrian Hirarchical Token Bucket untuk Management Bandwidth Jaringan Internet," J. RESTI (Rekayasa Sist. dan Teknol. Informasi), vol. 2, no. 2, pp. 522529, 2018.

[5] C. P. Antodi, A. B. Prasetijo, and E. D. Widianto, "Penerapan Quality of Service Pada Jaringan Internet Menggunakan Metode Hierarchical Token Bucket,” J. Teknol. dan Sist. Komput., vol. 5, no. 1, p. 23, 2017.

[6] I. P. S. Sukri, "Analisa Peningkatan Kualitas Jaringan Dengan Penerapan Metode Antrian Hirarchical Token Bucket," pp. 375-380, 2018.

[7] Telecommunications and Internet Protocol Harmonization Over Networks (TIPHON), “Tr 101 329," Etsi, vol. 1, no. General aspects of Quality of Service (QoS), pp. 1-37, 1999.

[8] S. Agoes, A. Putranto, D. J. T. Elektro-fti, and U. Trisakti, "Simulasi Kualitas Layanan Voip Paket Cbq Dengan Mekanisme Link Sharing,' JETri, vol. 7, no. 1, pp. 41-64, 2007.

[9] M. K. Yahya-Imam, P. Sellapan, and V. Devi, "An Enhanced Bandwidth Management Scheme for Improved Quality of Service in Network Communication System,” Int. J. Electron. Electr. Eng., vol. 2, no. 2, pp. 147-152, 2014

[10] Azhari Muhamad, "Analisis Jaringan Dengan Parameter Randomize File Size Menggunakan Network Simulator ( Ns )," J. Inform. Mulawarman, vol. 6, no. 3, pp. 105-107, 2011.

[11] A. Hasdiyansyah, S. I. Lestariningati, T. N. Nizar, J. Teknik, and K. Unikom, "Manajemen Trafik Dan Bandwidth Menggunakan Metode Cbq ( Class Bassed Queue ) Berbasis Gnu / Linux Untuk Optimalisasi Cloud Computing," pp. 1-9.

[12] W. S. Bobanto, “Analisis Kualitas Layanan Jaringan Internet - 2014," Tek. Elektro dan Komput., pp. 80-87, 2014.

[13] Philip Kotler, Manajemen Pemasaran, Jilid 2. Jakarta: PT Prenhallindo, 2002.

[14] Supranto, Pengukuran Tingkat Kepuasan Pelanggan untuk Menaikkan Pangsa Pasar. Jakarta: Rineka Cipta, 2001.

[15] Ariansyah, Kasmad, and S. Wahyuningsih, "Studi kepuasan pelanggan terhadap kualitas layanan pita lebar pada jaringan bergerak seluler (The study of subscriber satisfaction on quality of broadband service on cellular mobile network)," Bul. Pos dan Telekomun., vol. 14, no. 2, p. 113, 2016.

[16] Prof. Dr. Sugiyono 2013, Metode Penelitian Kuantitatif, Kualitatif Dan R\&D, 19th ed. Bandung: Alfabeta, CV, 2013.

[17] Axence, "Axence NetTools 5.0 pro," 2018. [Online]. Available: https://axence.net/en/axence-nettools. di akses pada 24 Feb 2018

[18] Online http://speedtest.biznetnetworks.com/ di akses pada 13 Ags 2018 
[Halaman ini sengaja dikosongkan] 